\title{
Dry Matter Partitioning at Harvest and Yield of Maize (Zea mays L.) as Influenced by Integration of Various Nutrients
}

\author{
R.K. Yadav*, A. Verma, S.L. Yadav and H.K. Sumariya \\ Department of Agronomy, Rajasthan College of Agriculture, Maharana Pratap University of \\ Agriculture and Technology, Udaipur, Rajasthan 313001, India \\ *Corresponding author
}

\section{A B S T R A C T}

\begin{tabular}{|l|}
\hline Ke y w or d s \\
Maize, Dry matter \\
partitioning, \\
FYM, Yield. \\
\hline Article Info \\
\hline Accepted: \\
26 May 2017 \\
Available Online: \\
10 June 2017 \\
\hline
\end{tabular}

A field experiment was carried out in two successive years 2010 and 2011 during Kharif season to find out effect of various nutrient sources on dry matter partitioning at harvesting stage, and yields of maize (Zea mays L.). The results of present investigation revealed that maximum dry matter in leaves, stem, tassel and cob was accumulated under 100\% NPK+FYM $10 \mathrm{t}$ $\mathrm{ha}^{-1}$. Integrated use of FYM $10 \mathrm{t} \mathrm{ha}^{-1}$ with $100 \%$ NPK resulted in the highest grain (3994 $\left.\mathrm{kg} \mathrm{ha}^{-1}\right)$ and stover $\left(5836 \mathrm{~kg} \mathrm{ha}^{-1}\right)$ yield of maize.

\section{Introduction}

Among all food crops cereals rice and wheat have been under the main focus of this revolutionary progress however, maize, the queen of cereals occupies a pride place among cereal crops in India. It is emerged out as third most important food crop after rice and wheat. Maize a predominant Kharif crop in Sub humid southern plain of Rajasthan because it is a stable food crop for tribal belt. Maize is a exhaustive feeder of nutrients and continuous cropping results in substantial amounts that often exceed replacement by manure or fertilizer, leading ultimately to deterioration in soil (Usadadiya and Patel, 2013). Amongst the growth inputs, mineral nutrients play a significant role not only in exploiting the realizable potential of the crop but also to maintain nutrient balance in soil for crop production.
Thus, emphasis on mineral nutrition is very essential. For higher crop yields there is a need for the application of higher dose of fertilizers.

But the increased use of high analysis fertilizers and adaptation of high yielding cultivars having high demand of secondary and micro nutrients for enhancing crop productivity has resulted in their deficiencies due to continued removal from soil (Tiwari, 2008).

The finite natural reserves of these nutrients in soil are shrinking and are declining at a fast rate in the absence of their replenishment. Thus balanced fertilization of crops is needed for sustaining higher level of production and maintaining proper nutrient balance in soil. 


\section{Materials and Methods}

A field experiment was carried out under AllIndia coordinated Research Project on Long Term Fertilizer Experiment initiated in Kharif 1997 in two successive years during kharif 2010 and 2011 at instructional farm Rajasthan College of Agriculture, Udaipur to assess the effect of continuous application of plant nutrients through organic and inorganic sources and its combination on dry matter partitioning and yield of maize.

The experiment constituted in randomized block design with twelve treatments, viz. $100 \% \mathrm{NPK}\left(\mathrm{T}_{1}\right), 100 \% \mathrm{NPK}+\mathrm{Zn}\left(\mathrm{T}_{2}\right), \quad 100 \%$ $\mathrm{NPK}+\mathrm{Zn}+\mathrm{S} \quad\left(\mathrm{T}_{3}\right), \quad 100 \% \mathrm{NPK}+\mathrm{S}$ $\left(\mathrm{T}_{4}\right), 100 \% \mathrm{NPK}+$ seed treatment with Azotobacter $\left(\mathrm{T}_{5}\right)$, FYM $10 \mathrm{t} \mathrm{ha}^{-1}+100 \%$ NPK(-NPK of FYM) $\left(\mathrm{T}_{6}\right), 100 \%$ NPK + FYM $10 \mathrm{t} \mathrm{ha}^{-1}\left(\mathrm{~T}_{7}\right)$, FYM $20 \mathrm{tha}^{-1}\left(\mathrm{~T}_{8}\right), 150 \%$ $\operatorname{NPK}\left(\mathrm{T}_{9}\right), 100 \% \mathrm{NP}\left(\mathrm{T}_{10}\right), 100 \% \mathrm{~N}\left(\mathrm{~T}_{11}\right)$ and absolute control $\left(\mathrm{T}_{12}\right)$ were replicated four times.

The sources used for applying N, P and $\mathrm{K}$ were urea, di-ammonium phosphate (adjusted for its $\mathrm{N}$ content) and muriate of potash, respectively.

Gypsum and zinc sulphate $\left(\mathrm{ZnSO}_{4} .7 \mathrm{H}_{2} \mathrm{O}\right)$ were used to supply $\mathrm{S}$ and $\mathrm{Zn}$. The other sources of nutrients were FYM (farm yard manure) and biofertilizer (Azotobacter sp.). The dose of the NPK for maize was worked out according to the soil test fertilizer recommendation.

The $100 \%$ NPK dose in $\mathrm{kg} \mathrm{ha}^{-1}$ worked out was 120: 60: 30 for maize crop. The doses for sulphur and zinc were framed as $40 \mathrm{~kg} \mathrm{~S} \mathrm{ha}^{-1}$ and $5 \mathrm{~kg} \mathrm{Zn} \mathrm{ha}{ }^{-1}$, respectively while FYM was applied as per the treatments. Maize variety PEHM-2 was used as test crop with seed rate of $25 \mathrm{~kg} \mathrm{ha}^{-1}$ at inter row of $60 \mathrm{~cm}$ and plant to plant spacing of $20 \mathrm{~cm}$.

\section{Results and Discussion}

\section{Dry matter partitioning}

Maximum dry matter accumulation by leaves was recorded by integrated use of $100 \%$ NPK + FYM $10 \mathrm{t} \mathrm{ha}^{-1}$ in both the years, however, it was at par with $150 \%$ NPK.

Likewise stem dry matter production was highest in conjoint application of $100 \%$ NPK + FYM $10 \mathrm{t} \mathrm{ha}^{-1}$. It was at placed on same bar with $150 \%$ NPK and $100 \%$ NPK with sulphur application in both the years. Dry weight of tassel and cob also was registered under 100\% NPK + FYM $10 \mathrm{t} \mathrm{ha}^{-1}$.

The significant effects of these parameters as a consequence of FYM in conjugation with chemical fertilization are attributed to the favorable nutritional status of soil resulting into increased biomass production of the crop.

This may also be attributed to favorable effect of FYM on microbial activity and root proliferation in soil which caused solubilizing effect on native phosphorus and other nutrients.

However, as fertilizer dose increased, the beneficial effects decreases because due to excessive use of fertilizers resulting in over exploitation of nutrients particularly micronutrients. The results of combined use of fertilizers and FYM are in close agreement with the findings of Singh et al., (2009), Kumar and Dhar (2010) and Dilshad et al., (2010) (Table 1).

\section{Yield}

The highest grain yield was recorded by application of $100 \%$ NPK + FYM $10 \mathrm{t} \mathrm{ha}^{-1}$ and its performance was at par with $150 \%$ NPK in both the years. Next superior treatment in this regards was $150 \%$ NPK (Table 2). 
Table.1 Effect of integrated nutrient management on dry matter partitioning of maize

\begin{tabular}{|c|c|c|c|c|c|c|c|c|c|c|c|c|}
\hline \multirow{3}{*}{ Treatments } & \multicolumn{12}{|c|}{ Dry matter production (g) at harvest } \\
\hline & \multicolumn{3}{|c|}{ Leaves } & \multicolumn{3}{|c|}{ Stem } & \multicolumn{3}{|c|}{ Tassel } & \multicolumn{3}{|l|}{ Cob } \\
\hline & 2010 & 2011 & pooled & 2010 & 2011 & pooled & 2010 & 2011 & pooled & 2010 & 2011 & pooled \\
\hline $100 \% \mathrm{NPK}$ & 11.32 & 11.17 & 11.24 & 27.02 & 26.86 & 26.94 & 5.43 & 5.23 & 5.33 & 119.12 & 118.42 & 118.77 \\
\hline $100 \% \mathrm{NPK}+\mathrm{Zn}$ & 11.44 & 11.30 & 11.37 & 27.45 & 27.30 & 27.37 & 5.36 & 5.16 & 5.26 & 119.82 & 119.13 & 119.47 \\
\hline $100 \% \mathrm{NPK}+\mathrm{S}+\mathrm{Zn}$ & 11.35 & 11.20 & 11.27 & 27.92 & 27.78 & 27.85 & 5.47 & 5.27 & 5.37 & 126.67 & 126.05 & 126.36 \\
\hline $100 \% \mathrm{NPK}+\mathrm{S}$ & 11.96 & 11.83 & 11.89 & 27.52 & 27.37 & 27.44 & 5.35 & 5.14 & 5.24 & 120.85 & 120.17 & 120.51 \\
\hline $100 \%$ NPK + Azotobacter & 12.02 & 11.89 & 11.96 & 25.82 & 25.65 & 25.73 & 5.46 & 5.26 & 5.36 & 120.07 & 119.38 & 119.73 \\
\hline FYM $10 \mathrm{tha}^{-1}+100 \%$ NPK $(-\mathrm{NPK}$ of FYM) & 12.16 & 12.03 & 12.10 & 27.24 & 27.08 & 27.16 & 6.07 & 5.88 & 5.97 & 118.50 & 117.80 & 118.15 \\
\hline $100 \% \mathrm{NPK}+\mathrm{FYM} 10 \mathrm{t} \mathrm{ha}^{-1}$ & 12.43 & 12.30 & 12.37 & 32.39 & 32.29 & 32.34 & 6.42 & 6.23 & 6.33 & 131.67 & 131.10 & 131.39 \\
\hline FYM $20 \mathrm{t} \mathrm{ha}^{-1}$ & 10.97 & 10.82 & 10.89 & 24.78 & 24.60 & 24.69 & 5.19 & 4.99 & 5.09 & 109.62 & 108.82 & 109.22 \\
\hline $150 \% \mathrm{NPK}$ & 12.32 & 12.19 & 12.25 & 30.72 & 30.60 & 30.66 & 5.61 & 5.42 & 5.51 & 125.68 & 125.05 & 125.36 \\
\hline $100 \% \mathrm{NP}$ & 11.98 & 11.84 & 11.91 & 25.62 & 25.45 & 25.53 & 5.37 & 5.17 & 5.27 & 107.96 & 107.15 & 107.56 \\
\hline $100 \% \mathrm{~N}$ & 10.36 & 10.21 & 10.29 & 24.55 & 24.37 & 24.46 & 5.25 & 5.05 & 5.15 & 103.28 & 102.43 & 102.85 \\
\hline Control & 7.21 & 7.03 & 7.12 & 15.69 & 15.42 & 15.56 & 4.57 & 4.36 & 4.46 & 79.78 & 78.69 & 79.24 \\
\hline S.Em. \pm & 0.43 & 0.44 & 0.31 & 0.63 & 0.63 & 0.44 & 0.24 & 0.25 & 0.17 & 2.18 & 2.20 & 1.55 \\
\hline C.D. $(P=0.05)$ & 1.25 & 1.26 & 0.87 & 1.80 & 1.82 & 1.26 & 0.70 & 0.71 & 0.49 & 6.27 & 6.33 & 4.37 \\
\hline
\end{tabular}

Table.2 Effect of integrated nutrient management on grain and Stover yield of maize

\begin{tabular}{|c|c|c|c|c|c|c|}
\hline \multicolumn{7}{|l|}{ Yield $\left(\mathrm{kg} \mathrm{ha}^{-1)}\right.$} \\
\hline \multirow[b]{2}{*}{ Treatments } & \multicolumn{2}{|l|}{ Grain } & \multicolumn{3}{|c|}{ Stover } & \multirow[b]{2}{*}{ pooled } \\
\hline & 2010 & 2011 & pooled & 2010 & 2011 & \\
\hline $100 \%$ NPK & 3408 & 3194 & 3301 & 5218 & 4749 & 4984 \\
\hline $100 \% \mathrm{NPK}+\mathrm{Zn}$ & 3595 & 3290 & 3442 & 5507 & 4871 & 5189 \\
\hline $100 \% \mathrm{NPK}+\mathrm{S}+\mathrm{Zn}$ & 3690 & 3487 & 3589 & 5556 & 5187 & 5371 \\
\hline $100 \% \mathrm{NPK}+\mathrm{S}$ & 3460 & 3274 & 3367 & 5324 & 4845 & 5085 \\
\hline $100 \%$ NPK + Azotobacter & 3508 & 3377 & 3442 & 5342 & 4991 & 5167 \\
\hline FYM $10 \mathrm{t} \mathrm{ha}^{-1}+100 \%$ NPK $(-$ NPK of FYM $)$ & 3469 & 3440 & 3454 & 5322 & 5201 & 5261 \\
\hline $100 \% \mathrm{NPK}+\mathrm{FYM} 10 \mathrm{t} \mathrm{ha}^{-1}$ & 4075 & 3912 & 3994 & 6055 & 5618 & 5836 \\
\hline FYM $20 \mathrm{t} \mathrm{ha}^{-1}$ & 2360 & 2364 & 2362 & 3540 & 3487 & 3514 \\
\hline $150 \% \mathrm{NPK}$ & 3777 & 3698 & 3737 & 5567 & 5585 & 5576 \\
\hline $100 \% \mathrm{NP}$ & 2950 & 2779 & 2865 & 4556 & 4197 & 4376 \\
\hline $100 \% \mathrm{~N}$ & 2337 & 2137 & 2237 & 3687 & 3274 & 3480 \\
\hline Control & 1438 & 1285 & 1362 & 2241 & 1940 & 2091 \\
\hline S.Em. \pm & 103 & 106 & 74 & 165 & 184 & 124 \\
\hline C.D. $(\mathrm{P}=0.05)$ & 297 & 304 & 208 & 475 & 529 & 349 \\
\hline
\end{tabular}


The treatment receiving 100\% NPK and its combination with $\mathrm{Zn}, \mathrm{Zn}+\mathrm{S}$, Azotobacter seed treatment and FYM $10 \mathrm{t} \mathrm{ha}^{-1}+100 \%$ NPK (NPK of FYM) showed statistically equivalent results in raising grain yield on pooled basis. The application of $100 \%$ NPK with FYM $10 \mathrm{t}$ $\mathrm{ha}^{-1}$ produced highest Stover yield $(5836 \mathrm{~kg}$ $\mathrm{ha}^{-1}$ ) on pooled basis and the result of which was statistically at par to $150 \%$ NPK. Results showed that integration of $100 \%$ NPK with FYM $10 \mathrm{t} \mathrm{ha}^{-1}$ brought about significant improvement in yield over unfertilized control and $100 \%$ NPK. This indicated a favourable soil micro climate régime induced by the incorporation of FYM. Application of FYM reduces $\mathrm{P}$ fixation by releasing considerable aborints and variety of organic acids during deposition and as well as inducing chelating effects on micronutrients which probably enhanced the availability of phosphorus (Behera and Singh (2009). Applications of FYM not only solubilize the availability of micronutrients but also contains significant amount of N, P and K. Thus application of FYM has resulted in an overall significant increase in uptake of nutrients at lesser cost but longer in durability or duration. These are in confirmation with findings of Behera and Singh, (2009) and Das et al., (2010).

\section{References}

Das, A., Patel, D.P., Munda, G.C. and Ghosh, P.K. 2010. Effect of organic and inorganic sources of nutrients on yield, nutrient uptake and soil fertility of maize (Zea mays) - mustard (Brassica campestris) cropping system. Indian Journal of Agricultural Sciences 80:8588.

Dilshad, M.D., Lone, M.I., Jilani, G., Azim Malik, M., Yousaf, M., Khalid, R., Shamin, F., 2010. Integrated nutrient management (IPNM) on maize under rainfed condition Pakistan Journal of Nutrition 9: 896-901.

Kumar, A., and Dhar, S. 2010. Evaluation of organic and inorganic sources of nutrients in maize (Zea mays) and their residual effect on wheat (Triticum aestivum) under different fertility levels. Indian Journal of Agricultural Sciences 80:364-371.

Scharf P.C. and Lory, J.A. 2002. Calibrating corn color from aerial photographs to predict side dress nitrogen need. Agronomy Journal 94:397-404.

Singh, G., Marwaha, T.S. and Kumar, D. 2010. Effect of resource conserving techniques on soil microbiological parameters under long term maize (Zea mays)-wheat (Triticum aestivum) crop rotation. Indian Journal of Agricultural Sciences 79: 94-100

Tiwari. K.N. 2008. Future plant nutrition research in India. Journal of Indian Society of Soil Science56:327-336.

Usadadiya V.P. and Patel, R.H. Influence of preceding crops and nutrient management on productivity of wheatbased cropping system. Indian journal of Agronomy 58: 15-18.

\section{How to cite this article:}

Yadav, R.K., A. Verma, S.L. Yadav and Sumariya, H.K. 2017. Dry Matter Partitioning at Harvest and Yield of Maize (Zea mays L.) as Influenced by Integration of Various Nutrients. Int.J.Curr.Microbiol.App.Sci. 6(6): 2942-2945. doi: https://doi.org/10.20546/ijcmas.2017.606.349 